\title{
Early disseminated Lyme disease
}

\author{
Patrick D. Bender, Jonathan S. Ilgen
}

Emergency Medicine, University of Washington, Seattle, Washington, USA

\section{Correspondence to} Dr Jonathan S. Ilgen, ilgen@uw.edu

Accepted 17 April 2018

\section{DESCRIPTION}

A 47-year-old man presented to the emergency department with fatigue and a rash. Two weeks prior to presentation, he had noticed a painful lesion in his left antecubital fossa (figure 1), which had gradually increased in size. Ten days later, he developed malaise, diffuse joint aches and a new rash (figure 2) over his torso, arms and legs. He had no palpitations, joint swelling or neurologic changes. Prior to the onset of his symptoms, he had vacationed in Wisconsin in early June-a Lyme-endemic region of the USA-and suspected that he may have had a tick bite to his left arm in the region adjacent to his initial rash. Physical exam was remarkable for a painful, indurated, erythematous plaque in the left antecubital fossa and multiple painless, erythematous patches with central clearing across his torso. He was afebrile, had no joint swelling or erythema and had no focal neurologic deficits. An ECG was normal, with no atrioventricular block, and a complete blood count and chemistry panel were unremarkable. The patient was clinically diagnosed with early disseminated Lyme disease and started on oral doxycycline for 3 weeks. Lyme serology studies drawn in the emergency department later returned with elevated IgM antibodies, supporting the diagnosis. On completion of treatment, the patient had complete resolution of his symptoms.

Lyme disease is the clinical manifestation of infection by Borrelia burgdorferi, a spirochete

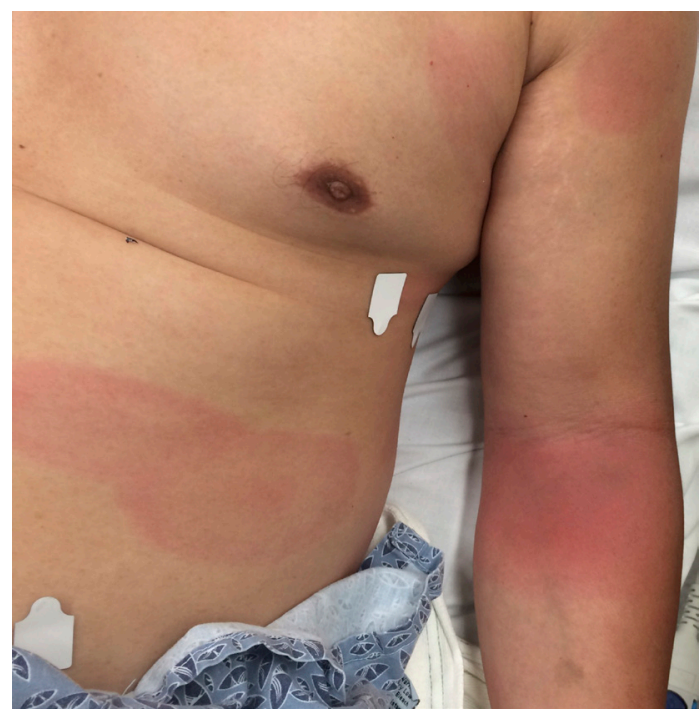

Figure 1 The initial erythema migrans lesion (right), manifest as a homogeneous, erythematous plaque in the left antecubital fossa, as well as an erythematous patch on his abdominal wall demonstrating the less commonly seen 'bull's-eye' appearance of early disseminated Lyme disease.

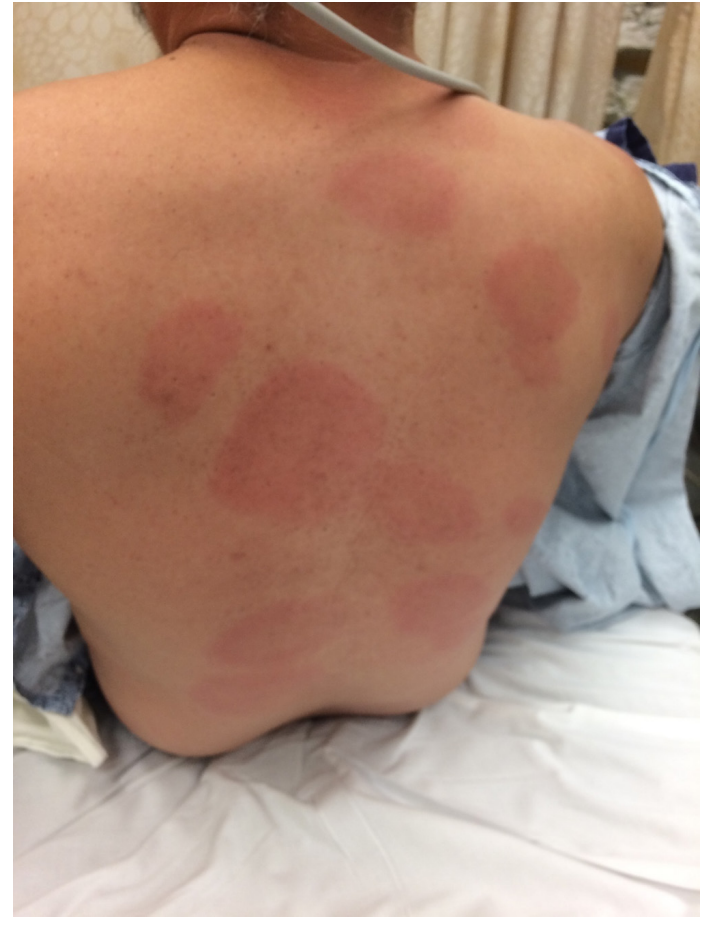

Figure 2 Multiple erythema migrans lesions on the patient's back corresponding to haematogenous spread in early disseminated Lyme disease, manifest as circular, homogeneous, erythematous patches.

transmitted by the bite of the Ixodes scapularis or Ixodes pacificus tick. ${ }^{1}$ These arthropods are endemic to the Northeast, Midwest and Pacific Coast regions of the USA and the vast majority of Lyme disease cases correspond to individuals who live, or travel to, these regions. ${ }^{1}$ Following a bite from the Ixodes tick, patients with Lyme disease typically present with erythema migrans (EM) at the bite site, classically described as a 'bull's-eye' pattern but more

\section{Learning points}

- Erythema migrans (EM) is the hallmark lesion of early Lyme disease, classically described as a bull's-eye pattern though more commonly manifest as a homogeneous patch. Multiple forms of EM are possible in early disseminated Lyme disease.

- Practitioners should have a high suspicion for neurologic and cardiac complications in early disseminated Lyme disease.

- Oral doxycycline is the antibiotic of choice for outpatient management of early disseminated Lyme disease, while late disseminated Lyme disease requires parenteral antibiotics. 
commonly manifest as circular, homogeneous erythema. ${ }^{12}$ In the following weeks, the spirochete undergoes haematogenous spread, and early disseminated Lyme disease presents with variable cutaneous findings of EM, such as erythematous rings with central clearing, erythematous plaques or purpura. ${ }^{13}$ Neurologic complications, including cranial nerve palsies, radiculopathies, meningitis and rarely encephalitis, can be seen in early disseminated Lyme disease. Myopericarditis is also possible, typically presenting with atrioventricular block. ${ }^{1}$ Late disseminated Lyme disease often causes the neurologic and cardiac manifestations of early disease, as well as a migratory monoarticular or pauciarticular arthritis of large joints. ${ }^{13}$

Diagnosis of Lyme disease can be made based on the cutaneous findings alone, or by serologic testing, though antibodies may not be detectable in patients with EM during the early phase of disease. ${ }^{1}$ Guidelines for treatment depend on the symptoms present and the stage of illness. Early and early disseminated Lyme disease, even with cardiac involvement and cranial nerve palsies, may be treated with 14 days of doxycycline. Patients with Lyme meningitis, encephalitis, radiculopathies, symptomatic carditis or arthritis refractory to initial oral therapy require a 14-day course of parenteral antibiotic therapy, typically ceftriaxone. $^{3}$
Contributors PDB was involved in the care of the patient described in the case, wrote the manuscript, contributed to the editorial process and provided the photographs submitted. JSI was also involved in the clinical care of the patient, contributed significantly to edits and alterations to the manuscript and provided editorial guidance. Both PDB and JSI have approved of the manuscript submitted.

Funding The authors have not declared a specific grant for this research from any funding agency in the public, commercial or not-for-profit sectors.

Competing interests None declared.

Patient consent Obtained.

Provenance and peer review Not commissioned; externally peer reviewed.

(C) BMJ Publishing Group Ltd (unless otherwise stated in the text of the article) 2018. All rights reserved. No commercial use is permitted unless otherwise expressly granted.

\section{REFERENCES}

1 Sanchez E, Vannier E, Wormser GP, et al. Diagnosis, treatment, and prevention of Lyme Disease, Human Granulocytic Anaplasmosis, and Babesiosis: a review. JAMA 2016;315:1767-77.

2 Smith RP, Schoen RT, Rahn DW, et al. Clinical characteristics and treatment outcome of early Lyme disease in patients with microbiologically confirmed erythema migrans. Ann Intern Med 2002;136:421-8.

3 Wormser GP, Dattwyler RJ, Shapiro ED, et al. The clinical assessment, treatment, and prevention of lyme disease, human granulocytic anaplasmosis, and babesiosis: clinical practice guidelines by the Infectious Diseases Society of America. Clin Infect Dis 2006;43:1089-134.

Copyright 2018 BMJ Publishing Group. All rights reserved. For permission to reuse any of this content visit

http://group.bmj.com/group/rights-licensing/permissions.

BMJ Case Report Fellows may re-use this article for personal use and teaching without any further permission.

Become a Fellow of BMJ Case Reports today and you can:

- Submit as many cases as you like

- Enjoy fast sympathetic peer review and rapid publication of accepted articles

- Access all the published articles

Re-use any of the published material for personal use and teaching without further permission

For information on Institutional Fellowships contact consortiasales@bmjgroup.com

Visit casereports.bmj.com for more articles like this and to become a Fellow 